(c) American Dairy Science Association, 2006.

\title{
Fate of Staphylococcus aureus in Cheese Treated by Ultrahigh Pressure Homogenization and High Hydrostatic Pressure
}

\author{
T. López-Pedemonte, W. J. Brinẽz, A. X. Roig-Sagués, ${ }^{1}$ and B. Guamis \\ Centre Especial de Recerca, Planta de Tecnologia Dels Aliments, CeRTA, XiT, Departament de Ciència Animal I dels Aliments, \\ Facultat de Veterinària, Universitat Autònoma de Barcelona, 08193 Bellaterra, Spain
}

\begin{abstract}
We evaluated the influence of ultrahigh pressure homogenization (UHPH) treatment applied to milk containing Staphylococcus aureus CECT 976 before cheese making, and the benefit of applying a further high hydrostatic pressure (HHP) treatment to cheese. The evolution of Staph. aureus counts during $30 \mathrm{~d}$ of storage at $8^{\circ} \mathrm{C}$ and the formation of staphylococcal enterotoxins were also assessed. Milk containing approximately 7.3 $\log _{10} \mathrm{cfu} / \mathrm{mL}$ of Staph. aureus was pressurized using a 2-valve UHPH machine, applying 330 and $30 \mathrm{MPa}$ at the primary and the secondary homogenizing valves, respectively. Milk inlet temperatures $\left(T_{i n}\right)$ of 6 and $20^{\circ} \mathrm{C}$ were assayed. Milk was used to elaborate soft-curd cheeses (UHPH cheese), some of which were additionally submitted to 10-min HHP treatments of $400 \mathrm{MPa}$ at $20^{\circ} \mathrm{C}$ (UHPH+HHP cheese). Counts of Staph. aureus were measured on $\mathrm{d} 1$ ( $24 \mathrm{~h}$ after manufacture or immediately after HHP treatment) and after 2, 15, and $30 \mathrm{~d}$ of ripening at $8^{\circ} \mathrm{C}$. Counts of control cheeses not pressuretreated were approximately $8.5 \log _{10} \mathrm{cfu} / \mathrm{g}$ showing no significant decreases during storage. In cheeses made from UHPH treated milk at $T_{\text {in }}$ of $6^{\circ} \mathrm{C}$, counts of Staph. aureus were $5.0 \pm 0.3 \log _{10} \mathrm{cfu} / \mathrm{g}$ at $\mathrm{d} 1$; they decreased significantly to $2.8 \pm 0.2 \log _{10} \mathrm{cfu} / \mathrm{g}$ on d 15 , and were below the detection limit $\left(1 \log _{10} \mathrm{cfu} / \mathrm{g}\right)$ after $30 \mathrm{~d}$ of storage. The use of an additional HHP treatment had a synergistic effect, increasing reductions up to $7.0 \pm$ $0.3 \log _{10} \mathrm{cfu} / \mathrm{g}$ from d 1 . However, for both UHPH and $\mathrm{UHPH}+\mathrm{HHP}$ cheeses in the $6^{\circ} \mathrm{C} T_{i n}$ samples, viable Staph. aureus cells were still recovered. For samples of the $20^{\circ} \mathrm{C} T_{\text {in }}$ group, complete inactivation of Staph. aureus was reached after $15 \mathrm{~d}$ of storage for both UHPH and UHPH+HHP cheese. Staphylococcal enterotoxins were found in controls but not in UHPH or UHPH+HHP treated samples. This study shows a new approach for significantly improving cheese safety by means of using UHPH or its combination with HHP.
\end{abstract}

Received March 30, 2006.

Accepted June 28, 2006.

${ }^{1}$ Corresponding author: arturxavier.roig@uab.es
Key words: Staphylococcus aureus, cheese, ultrahigh pressure homogenization, high hydrostatic pressure

\section{INTRODUCTION}

In the dairy industry, there is a growing interest in mild nonthermal processes, which combine efficient microorganism reduction with a maximum retention of the physicochemical properties of the product. Highpressure treatment of milk and dairy products is considered to be the most promising alternative to traditional thermal treatments (Trujillo et al., 2002; Hayes and Kelly, 2003). Over the last 15 yr, many aspects concerning the effects of high hydrostatic pressure (HHP) on cheese and dairy products have been investigated (O'Reilly et al. 2001; Patterson, 2005). Ultrahigh pressure homogenization (UHPH, also known as high pressure homogenization or dynamic high pressure) works at pressures greater than $200 \mathrm{MPa}$ (Hayes and Kelly, 2003; Thiebaud et al., 2003) and is currently the subject of intensive research. The UHPH machines incorporate important technological developments to conventional homogenization, such as high pressure pumps and intensifiers, specifically designed high pressure valves made of ceramic material known to withstand extremely high pressure levels (up to $400 \mathrm{MPa}$ ), and modified geometry compared with classical homogenizing valves (i.e., APV-Gaulin homogenizers), leading to differences in fluid flow direction and narrower gaps between the valve and the seats (Thiebaud et al., 2003; Floury et al., 2004). Ultrahigh pressure homogenization can be used to make fine food emulsions, to disrupt dense cell microbial cultures and subsequently recover intracellular metabolites, to inactivate bacteriophages, and to modify functional properties of hydrocolloids (Middelberg, 1995; Floury et al., 2002; Moroni et al., 2002; Hayes et al., 2004). In consequence, UHPH is now attracting increasing interest in the food area.

With both HHP and UHPH techniques, microorganisms are subjected to high pressures. Whereas the time of exposure is usually in the order of few minutes or more in HHP treatments, the residence time of the fluids in the high-pressure section is in the order of seconds in most cases in current UHPH machines (Thie- 
baud et al., 2003). Microbial cells are destroyed by HHP, which induces changes in the morphology, the cell membrane and the wall of microorganisms, and modifies biochemical reactions and genetic mechanisms (Patterson, 2005). Inactivation of bacteria in high-pressure homogenization processes is achieved by pressure, exposure to hydrodynamic cavitations, impingement against static surfaces, and high turbulence and fluid shear. The temperature increase due to heat dissipation of kinetic energy in the high-pressure valve also contributes to inactivation (Wuytack et al., 2002; Hayes and Kelly, 2003; Thiebaud et al., 2003). However, the residence time of the fluid at the temperature reached after it passes the high-pressure valve can be less than $1 \mathrm{~s}$ if the heat-exchanger devices are placed immediately after this valve (Thiebaud et al., 2003; Picart et al., 2006). For both kinds of high-pressure treatments, the initial load of vegetative cells and the different matrixes holding the target bacteria also influence the resulting inactivation (Patterson et al., 1995; Vachon et al., 2002).

In general, resistance to pressure diminishes from spores to gram-positive and gram-negative bacteria (Wuytack et al., 2002). One of the most HHP- and UHPH-resistant nonsporulating gram-positive bacteria is Staphylococcus aureus (Patterson et al., 1995; Wuytack et al., 2002). Staphylococcus aureus is commonly found in milk and dairy products, particularly in cheeses made either from raw or pasteurized milk (Coveney et al., 1994), due to it being among the most important etiological agents of bovine mastitis and because it is extensively carried by food industry workers (Younis et al., 2003). Staphylococcus aureus is also one of the main agents of food intoxication caused by milk and dairy product consumption in France, Spain, and the United Kingdom (Brisabois et al., 1997; European Union, 2003). It is still one of the leading causes of foodborne illness worldwide and the second most commonly reported cause in the United States (Bunning et al., 1997; Balaban and Rasooly, 2000; Jablonski and Bohach, 2001; Younis et al., 2003). The most notable virulence factors associated with Staph. aureus are staphylococcal enterotoxins (StE). They are heat-stable proteins that are produced by approximately $25 \%$ of the Staph. aureus isolated from foods. They function as potent gastrointestinal toxins; in susceptible individuals, they may produce nausea, vomiting, diarrhea, abdominal cramps, and malaise 3 to $10 \mathrm{~h}$ after consumption. Staphylococcal enterotoxin A is the most common StE found in food-poisoning outbreaks in the United States (Balaban and Rasooly, 2000; Cenci-Goga et al., 2003).

Inactivation of Staph. aureus in milk and dairy products by HHP has been extensively studied (Patterson et al., 1995; Gervilla et al., 1999; López-Pedemonte et al., 2007). In contrast, few studies of inactivation of Staph. aureus using UHPH have been performed. Staphylococcus aureus reduction in PBS $(10 \mathrm{mM}$ potassium phosphate, $\mathrm{pH} 7.0 ; 8.4 \mathrm{~g} / \mathrm{L}$ of $\mathrm{NaCl}$ ) under UHPH up to $300 \mathrm{MPa}$ are barely significant at temperatures lower than $45^{\circ} \mathrm{C}$ (Wuytack et al., 2002; Diels et al., 2003). Wuytack et al. (2002) also observed that consecutive rounds of HHP or UHPH have an additive effect on the viability reduction of bacteria. However, no published reports have been found involving the use of a combination of both treatments. Microorganisms are inactivated by HHP and UHPH by different mechanisms. The successive application of both technologies can be seen as additional hurdles against pathogen cells. Examples can be found in previous works involving combinations of temperatures higher than $50^{\circ} \mathrm{C}$ with HHP or pulsed electric fields (Gervilla et al., 1999; Rowan et al., 2001) and HHP treatments applied to foods containing bacteriocins (López-Pedemonte et al., 2003; Arqués et al., 2005).

Several studies with food as the assay medium have demonstrated the influence of the food matrix on microbial sensitivity to HHP (Patterson et al., 1995; Patterson, 2005) and thus the importance of choosing the right matrix. Model cheeses are more similar to real cheese than slurries and tube tests. They offer the possibility of testing single strains in a real cheese environment and they allow us also to use pathogenic strains and to keep them confined within a controlled laboratory. The objective of this work was to study the inactivation of Staph. aureus in model cheeses made from inoculated UHPH-treated milk. The benefit of adding a further HHP treatment $24 \mathrm{~h}$ after cheese production, the evolution of Staph. aureus counts during $30 \mathrm{~d}$ of ripening at $8^{\circ} \mathrm{C}$, and the probable formation of $\mathrm{StE}$ were also evaluated.

Experimental conditions for this study were chosen taking into consideration previous studies in which UHPH and HHP treatments were applied to milk and cheese samples. The aim was to test the performance of UHPH treatment previous to cheese making as an alternative to traditional thermal treatments. Recently, Briñez et al. (Universitat Autònoma de Barcelona, Barcelona, Spain, personal communication) found reductions of approximately 3 to $4 \log _{10} \mathrm{cfu} / \mathrm{mL}$ of Staph. aureus in milk, applying $300 \mathrm{MPa}$ with a milk inlet temperature of $20^{\circ} \mathrm{C}$. Hence, it seemed reasonable to apply the highest pressure treatment the equipment can reach without excessive fluctuation (330 MPa). Two UHPH milk inlet temperatures in the feeding tank $\left(\boldsymbol{T}_{\boldsymbol{i n}}\right)$ were selected: 6 and $20^{\circ} \mathrm{C}$. Temperatures of $6^{\circ} \mathrm{C}$ can often be encountered in raw milk bulk tanks of dairy farms and processing industries, and UHPH treatment at this temperature would permit its incorporation to 
milk continuous processing. Although not all milk lipids are in liquid state at $6^{\circ} \mathrm{C}$, milk is fluid enough to circulate through the homogenizer. This $T_{i n}$ is thought to produce a lower milk temperature after the high-pressure valve. On the contrary, a $T_{\text {in }}$ of $20^{\circ} \mathrm{C}$ would produce a higher milk temperature after the high-pressure valve, and thus was chosen to increase the thermal contribution to Staph. aureus inactivation. The aim of applying an HHP treatment after UHPH was to cause additional destruction to the UHPH-treated cells. This additional HHP treatment was applied to some 24-h cheeses (before the 30-d storage period), aiming to benefit from the effects of the ripening process coupled to HHP treatment and to reduce Staph. aureus number below the level at which enterotoxin formation may occur (López-Pedemonte et al., 2007). Based upon studies with milk and Cheddar cheese (Gervilla et al., 1999; O'Reilly et al., 2000) and model cheese studies with the same strain of Staph. aureus (López-Pedemonte et al., 2007), $400 \mathrm{MPa}$ and $20^{\circ} \mathrm{C}$ were selected as the optimum pressure and temperature HHP treatment conditions. Higher pressures are expected to produce higher levels of inactivation, but they may also adversely affect cheese physicochemical characteristics and alter, if not arrest, its normal ripening (Malone et al., 2003; Juan et al., 2004; Wick et al., 2004).

\section{MATERIALS AND METHODS}

\section{Pasteurization of Milk}

Bovine raw milk was collected from a local farm and transported under refrigerated conditions to the laboratory in less than $1 \mathrm{~h}$. It was then pasteurized (30 min at $65^{\circ} \mathrm{C}$ and rapidly cooled) to avoid the interference of natural Staph. aureus or competitive bacteria, and stored below $4^{\circ} \mathrm{C}$ until cheese manufacture.

\section{Bacterial Strains}

Staphylococcus aureus CECT 976 is an enterotoxinA-producing strain and has been involved in one food poisoning incident (Belay and Rasooly, 2002). It was also chosen because of its high baroresistance shown in previous experiments (Patterson et al., 1995; LópezPedemonte et al., 2007). It was obtained as a freezedried culture in thermo-sealed vials from the Colección Española de Cultivos Tipo (CECT, University of Valencia, Valencia, Spain) and corresponds to number 13565 of the American Type Culture Collection (Manassas, VA). Freeze-dried cultures were rehydrated in tryptone soy broth (Oxoid Ltd., Basingstoke, UK) at $37^{\circ} \mathrm{C}$ for 18 h. Subsequently, these broths were used to inoculate tryptone soy agar plates (Oxoid), and individual colonies were collected to prepare cryobeads (Nalgene Sys- tem 100 Laboratories, Microkit Iberica S.L., Madrid, Spain). They were then kept at $-20^{\circ} \mathrm{C}$ to provide stock cultures for the assays.

\section{Preparation of Staph. aureus Suspension and Inoculation of Milk}

Before each experiment, $10 \mathrm{~mL}$ of tryptone soy broth was inoculated with Staph. aureus cells adsorbed on one cryobead and incubated at $37^{\circ} \mathrm{C}$ for $20 \mathrm{~h}$. After incubation, the broth was spread on tryptone soy agar inside a tube and left at $37^{\circ} \mathrm{C}$ for 20 to $24 \mathrm{~h}$ to obtain cells in the stationary phase of growth. Subsequently, cell suspensions were prepared in $11 \mathrm{~mL}$ of tryptone $\mathrm{NaCl}$ solution ( $1 \mathrm{~g} / \mathrm{L}$ of tryptone pancreatic casein digestion and $8.5 \mathrm{~g} / \mathrm{L}$ of $\mathrm{NaCl}$ ) to obtain 9.0 to $9.5 \log _{10} \mathrm{cfu} /$ $\mathrm{mL}$. One milliliter of cell suspension was used to determine the concentration by means of absorbance at 405 $\mathrm{nm}$ using a spectrophotometer (Cecil 9000 series, Cecil Instruments, Cambridge, UK). Thereafter, $10 \mathrm{~mL}$ of each cell suspension was inoculated into milk at room temperature. Milk-inoculated samples were left to stand for $70 \mathrm{~min}$ at $6 \pm 1^{\circ} \mathrm{C}$ or $20 \pm 1^{\circ} \mathrm{C}$ before pressure treatments. Milk destined to make cheese control samples (inoculated but not pressure treated) was inoculated at the same time as milk destined to be submitted to UHPH. The final concentration of cells in milk was approximately $7 \log _{10} \mathrm{cfu} / \mathrm{mL}$.

\section{UHPH Treatment of Milk}

The UHPH treatment was applied to samples using a Stansted high pressure homogenizer (model DRG FPG 7400H:350, Stansted Fluid Power Ltd., Essex, UK). This machine has a high-pressure valve made of resistant ceramics and is able to support up to $350 \mathrm{MPa}$. A second pneumatic valve located after the first one is able to support $50 \mathrm{MPa}$. The high-pressure system consists of 2 intensifiers ( $80 \mathrm{~mL}$ useful volume) driven by a hydraulic pump. To avoid loss of homogenization performance due to temperature increase and rapid expansions or contractions of the first stage valve, it is refrigerated by constant circulation of water at ambient temperature in an external jacket built around it. Milk samples were subjected to a single-pass UHPH treatment of $330 \mathrm{MPa}$ on the primary homogenizing valve and $30 \mathrm{MPa}$ on the secondary valve. The flow rate of the milk in the homogenizer was relatively constant (approximately $16 \mathrm{~L} / \mathrm{h}$ ) at the pressure assayed. Inlet temperatures of 6 and $20^{\circ} \mathrm{C}$ were assayed. The homogenized milk was rapidly cooled. It reached 16 to $18^{\circ} \mathrm{C}$ by means of another external jacket built around the pipeline connecting the first homogenizing valve and the second one, and a spiral type heat exchanger (BCI/ 
2843 type, Occo Cooler Ltd., Telford, UK) located after the second valve. For the different experiments carried out at each temperature, $10 \mathrm{~L}$ of inoculated milk was used. The majority of this volume was processed through the homogenizer to ensure temperature and pressure equilibration. Afterwards, milk was collected in sterilized 1-L bottles. Cleaning and disinfection of the UHPH equipment was made according to Briñez et al. (2006).

\section{Preparation of the Starter Culture}

A mixture of commercial lyophilized Lactococcus lactis ssp. lactis and Lactococcus lactis ssp. cremoris (Ezal MAO 11, Rhodia Iberia S.A., Madrid, Spain), known as a nonbacteriocin producer, was used as a starter culture for the washed-curd cheese manufacture. The culture was revived by placing $0.015 \mathrm{~g}$ of the mixture in $1,000 \mathrm{~mL}$ of commercial sterilized skimmed milk and incubated at $30^{\circ} \mathrm{C}$ for $24 \mathrm{~h}$. A volume of 50 $\mathrm{mL}$ was used to prepare a subculture in $200 \mathrm{~mL}$ of sterilized skimmed milk, which was also incubated at $30^{\circ} \mathrm{C}$ for $24 \mathrm{~h}$. The final concentration was approximately $9 \log _{10} \mathrm{cfu} / \mathrm{mL}$.

\section{Manufacture of Cheese}

Soft-curd cheeses of approximately $30 \mathrm{~g}$ were manufactured under controlled microbiological conditions following a modification of the procedure of Shakeel-UrRehman et al. (1998) as described by López-Pedemonte et al. (2003). Milk already inoculated with Staph. aureus and UHPH treated was brought to $31^{\circ} \mathrm{C}$ in a water bath and $2 \%(\mathrm{vol} / \mathrm{vol})$ starter culture was added together with $0.01 \%$ (vol $/ \mathrm{vol}$ ) of a $35 \%$ (wt/vol) $\mathrm{CaCl}$ solution (Arroyo, Santander, Spain) to improve coagulation. A liquid rennet extract $(0.02 \%, \mathrm{vol} / \mathrm{vol})$ of calf origin $(520 \mathrm{mg} / \mathrm{L}$ active chymosin, Arroyo) was used as coagulating agent. Milk was poured into previously sterilized, 225-mL long-necked centrifuge bottles. Coagulation took place at $31^{\circ} \mathrm{C}$. After 45 min curds were gently cut with sterile stainless steel tools and heated for $15 \mathrm{~min}$ at $37^{\circ} \mathrm{C}$. About $40 \%$ of whey was discarded and replaced by sterile tap water. Bottles were centrifuged at $7,000 \times g$ for $40 \mathrm{~min}$ at $20^{\circ} \mathrm{C}$. Then they were kept in the water bath at $37^{\circ} \mathrm{C}$ until $\mathrm{pH}$ reached 5.5. The whey was discarded and $20 \%$ sterile brine (200 g of $\mathrm{NaCl} / \mathrm{L}$ of tap water) was added directly into each bottle. After $15 \mathrm{~min}$, the brine was removed and cheeses were taken out of the bottles and dried with sterile paper. They were vacuum packed in plastic bags (bb4.l, Cryovac Packaging, Sant Boi de Llobregat, Spain) and stored at $8^{\circ} \mathrm{C}$ for $30 \mathrm{~d}$. A series of cheeses made with pasteurized milk (neither inoculated nor UHPH-pro-

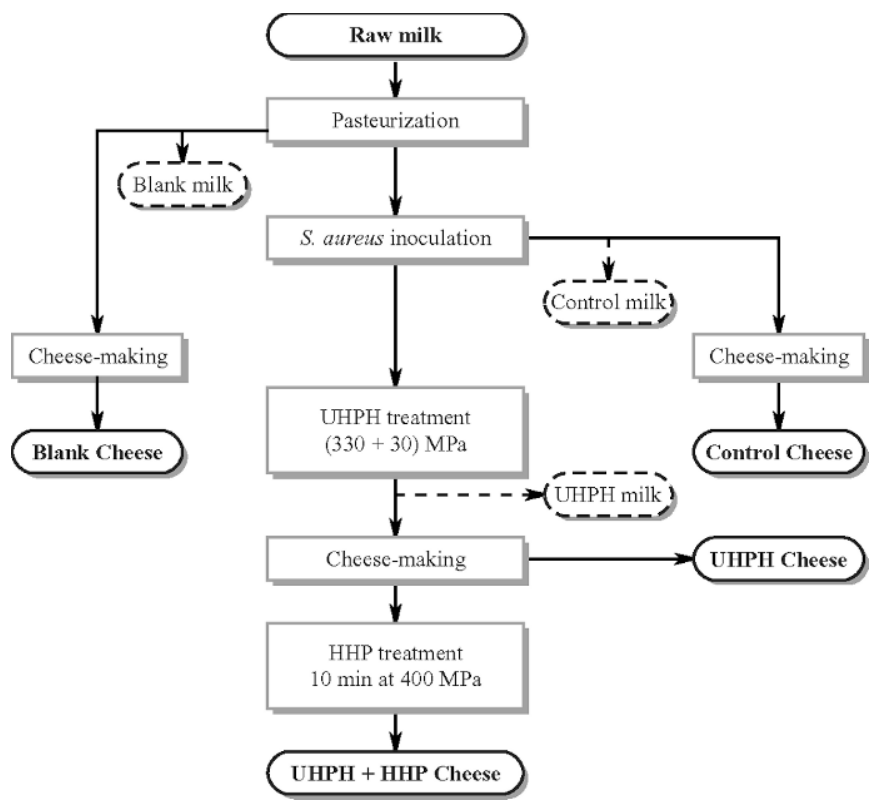

Figure 1. Flow chart showing the procedure for the production of the different series of cheeses made with milk treated with ultrahigh pressure (UHPH) and UHPH + high hydrostatic pressure (HHP).

cessed) was included to obtain blank cheeses. Figure 1 demonstrates the manufacturing of the different cheese series. Cheese making procedure was adjusted with cheese made of pasteurized milk to obtain a moisture content of approximately $45 \%$ and a $\mathrm{pH}$ of 5.5 after manufacture (López-Pedemonte et al., 2003). For cheese made of UHPH-treated milk, exactly the same procedure conditions were followed; thus in UHPH cheeses moisture is approximately $10 \%$ higher.

\section{HHP Treatments of Cheeses}

As can be seen in Figure 1, some of the samples were HHP-treated $24 \mathrm{~h}$ after manufacture using discontinuous HHP equipment (model S-FL-850-9-W, Stansted Fluid Power). This plunger-press-style vessel with internal high pressure intensifier has a pressure chamber with usable dimensions of $37 \mathrm{~mm}$ bore internal diameter $\times 245 \mathrm{~mm}$ long and houses inside the product loading canister. The vessel body and pressure-transmitting fluid inside (water) were held at treatment temperature by circulating water through an integral heat transfer jacket fitted to the outside of the high-pressure barrel assembly. The temperature was monitored with a thermocouple positioned in the transmission fluid in the upper part of the chamber. On each run, 2 vacuumpacked cheese samples (approximately $100 \mathrm{~cm}^{3}$ ) were placed inside the product canister. They were stabilized at $18 \pm 1^{\circ} \mathrm{C}$ and then immediately submitted to a 10 - 
min HHP treatment at $400 \mathrm{MPa}$ (as measured on the digital and analog pressure indicators). Average time of pressure increase was $90 \mathrm{~s}$ and average decompression time was $35 \mathrm{~s}$. Limit temperatures of the pressurizing fluid were as follows: maximum temperature under pressure, 28 to $30^{\circ} \mathrm{C}$; minimum temperature under pressure, 20 to $21^{\circ} \mathrm{C}$.

\section{Microbiological Analysis}

Microbiological milk analysis was carried out before and after UHPH treatment. Decimal dilutions were prepared in peptone water $(10 \mathrm{~g} / \mathrm{L}$ of peptone and $5 \mathrm{~g}$ of $\mathrm{NaCl} / \mathrm{L}$, Oxoid) and spread onto tryptone soy agar supplemented with $6 \mathrm{~g} / \mathrm{L}$ of yeast extract powder (Oxoid). Plates were then incubated at $37^{\circ} \mathrm{C}$ for $48 \mathrm{~h}$.

Microbiological cheese analysis was performed $24 \mathrm{~h}$ after manufacture or immediately after HHP treatment as appropriate (d 1). Cheeses were also analyzed after 2,15 , and $30 \mathrm{~d}$ of storage at $8^{\circ} \mathrm{C}$ by homogenizing $10 \mathrm{~g}$ of sample in $90 \mathrm{~mL}$ of tryptone soy broth supplemented with $6 \mathrm{~g} / \mathrm{L}$ of yeast extract powder in an electromechanical blender (BagMixer, Interscience, France). Decimal dilutions in peptone water were spread onto the surface of Baird Parker agar (Oxoid) and incubated at $37^{\circ} \mathrm{C}$ for 24 to $48 \mathrm{~h}$. On each analysis day, the remaining first dilutions in tryptone soy broth supplemented with yeast extract of every sample were incubated for $18 \mathrm{~h}$ at $32^{\circ} \mathrm{C}$. A loopful of this culture was streaked onto a plate of Baird Parker agar supplemented with rabbit plasmin fibrinogen (Oxoid) and incubated at $37^{\circ} \mathrm{C}$ to determine whether complete inactivation of Staph. aureus was achieved or not. When counts of Staph. aureus were below the detection limit $\left(1.0 \log _{10} \mathrm{cfu} / \mathrm{g}\right)$ but viable cells were recovered after the enrichment step, the assigned value was $0.99 \log _{10} \mathrm{cfu} / \mathrm{g}$. When no recovery was found, the assigned value was zero. Blank cheese samples (not inoculated with Staph. aureus) were included to assess the efficacy of the pasteurization and manufacturing processes. Inoculated model cheeses not submitted to any pressure treatment were called control cheeses (as shown in Figure 1).

Reductions were calculated by comparing counts of control samples $\left(\mathrm{N}_{0}\right)$ with those of pressure-treated samples $(\mathrm{N})$ as follows: Reduction $\left(\log _{10} \mathrm{cfu} / \mathrm{g}\right)=\log _{10}$ $\mathrm{N}_{0}-\log _{10} \mathrm{~N}$.

\section{StE Detection}

The presence or absence of StE was determined following the protocol for dairy samples of the VIDAS Staphylococcal Enterotoxin System II (SET2, enzymelinked fluorescent assay provided by bioMérieux s.a., Marcy L'Etoile, France). According to the manufac- turer, the sensitivity of this test in the detection of StE A in food samples is over $1.0 \mathrm{ng} / \mathrm{mL}$. Assays were made in $\mathrm{d} 1$ cheeses and in cheeses stored $30 \mathrm{~d}$ at $8^{\circ} \mathrm{C}$.

\section{Statistical Analysis}

Each HHP experiment was performed 3 separate times with duplicate analysis in each replicate. The GLM procedure as implemented in SPSS 12.0 for Windows (SPSS Inc., Chicago, IL) was used to test effects on the colony count logarithm of Staph. aureus of the following factors: pressure treatment; $T_{i n}$; and storage day. A posthoc Tukey test was used to obtain paired comparisons among sample means on each storage day. A one-way repeated-measures ANOVA was performed with storage day as factor for testing the main effect on counts of Staph. aureus on every combination of pressure treatments (UHPH alone, UHPH + HHP, no pressure treatment) and $T_{\text {in }}\left(6\right.$ and $\left.20^{\circ} \mathrm{C}\right)$. Level of significance was $P<0.05$.

\section{RESULTS}

\section{Reduction of Counts of Staph. aureus in Milk}

Initial Staph. aureus counts of inoculated milk destined to be UHPH treated at $T_{\text {in }}$ of 6 and $20^{\circ} \mathrm{C}$ can be seen in Figure 2. Reductions of Staph. aureus counts in these milk samples as a consequence of UHPH treatments at $6^{\circ} \mathrm{C} T_{\text {in }}$ were inferior to those obtained at $20^{\circ} \mathrm{C} T_{i n}\left(2.1 \pm 0.1\right.$ vs. $3.6 \pm 0.2 \log _{10} \mathrm{cfu} / \mathrm{g}$, respectively, $P=0.003)$.

\section{Initial Counts of Staph. aureus in Cheese}

Figure 3 shows the counts of Staph. aureus in control and in UHPH cheeses. Counts of Staph. aureus in control cheeses were higher than those found in inoculated milk, as normally occurs. When vegetative cells of a certain microorganism are inoculated into milk destined for cheese making, their counts in the obtained cheese are higher. This is mainly due to the concentration process that takes place and to their growth at moderate temperatures (in this case 31 to $37^{\circ} \mathrm{C}$ for $3 \mathrm{~h}$ ).

As reflected in these initial figures, $T_{\text {in }}$ affected the counts obtained in UHPH cheeses $(P<0.001)$. The initial differences between counts of Staph. aureus in control and UHPH cheeses were $3.7 \pm 0.1$ and $7.6 \pm 0.1$ $\log _{10} \mathrm{cfu} / \mathrm{g}$ for 6 and $20^{\circ} \mathrm{C} T_{i n}$, respectively. For both temperatures assayed, these values were higher than the reductions of Staph. aureus found in milk before and after UHPH treatment.

In UHPH+HHP cheeses for $T_{\text {in }}$ of $6^{\circ} \mathrm{C}$, the additional HHP treatment increased the reduction of counts of Staph. aureus from $3.7 \pm 0.1$ to $7.0 \pm 0.5 \log _{10} \mathrm{cfu} / \mathrm{g}$. This 


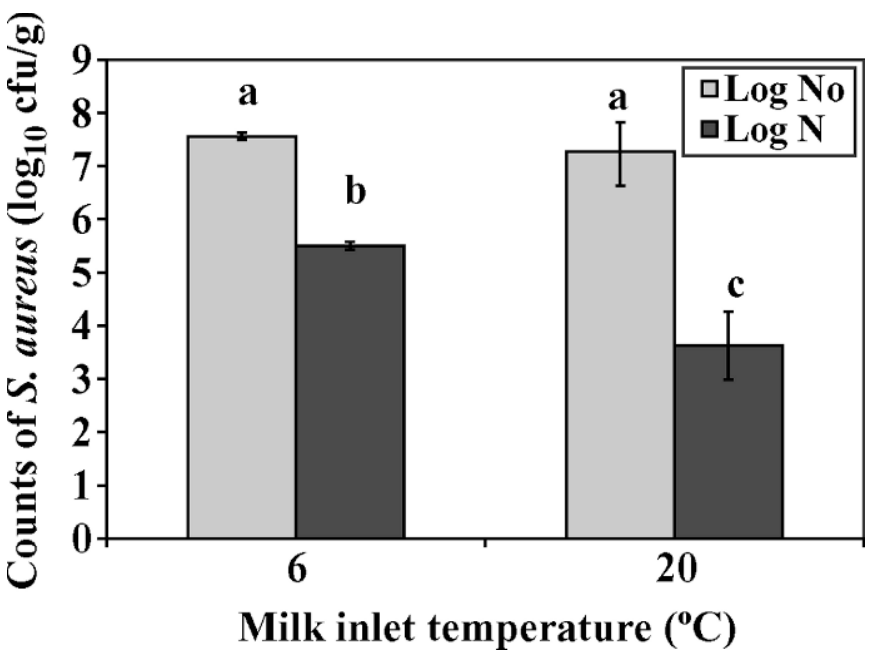

Figure 2. Counts of Staphylococcus aureus CECT 976 (expressed as means of 3 replications \pm confidence interval) in milk before and after ultrahigh pressure homogenizing treatment of $330 \mathrm{MPa}$ (first valve) and $30 \mathrm{MPa}$ (second valve), at inlet temperatures of 6 and $20^{\circ} \mathrm{C}$. No = initial counts of Staph. aureus in milk samples; $\mathrm{N}=$ counts of Staph. aureus in the same milk after ultrahigh pressure homogenizing treatment. Different letters above bars indicate significant difference among the means $(P<0.05)$.

difference between UHPH and UHPH+HHP cheeses reflected the effect of HHP. This effect was not seen for $20^{\circ} \mathrm{C} T_{i n}$ because with the UHPH treatment alone, Staph. aureus counts were below the detection limit of our technique.

\section{Evolution of Counts of Staph. aureus During $30 d$ of Storage at $8^{\circ} \mathrm{C}$}

Counts of Staph. aureus in control cheeses for both $T_{i n}$ did not differ during storage $(P=0.174$ and $P=$ 0.093 for 6 and $20^{\circ} \mathrm{C}$, respectively) as can be seen in Figure 3. In contrast, counts of most pressure-treated samples decreased with storage time.

The counts of Staph. aureus during the 30-d storage period at $8^{\circ} \mathrm{C}$ (i.e., counts on $\mathrm{d} 2,15$, and 30 relative to d 1 counts) in cheeses made from milk UHPH treated at $T_{\text {in }}$ of $6^{\circ} \mathrm{C}$ diminished from d 2 to 30 of storage $(P<$ $0.001)$. The difference in Staph. aureus counts between these cheese samples reached $3.9 \pm 0.3 \log _{10} \mathrm{cfu} / \mathrm{g}$. For samples that received the additional HHP cycle of 400 $\mathrm{MPa}$, counts were below the detection limit on $\mathrm{d} 1$ and did not vary during their storage at $8^{\circ} \mathrm{C}(P=0.190)$. Nevertheless, after incubating the initial dilution of the samples for $18 \mathrm{~h}$ at $32^{\circ} \mathrm{C}$ and streaking onto selective agar (Baird Parker supplemented with rabbit plasmin fibrinogen), characteristic colony growth showed that some Staph. aureus cells were able to recover.

In both UHPH and UHPH+HHP cheeses made from milk treated at $T_{\text {in }}$ of $20^{\circ} \mathrm{C}$, counts of Staph. aureus
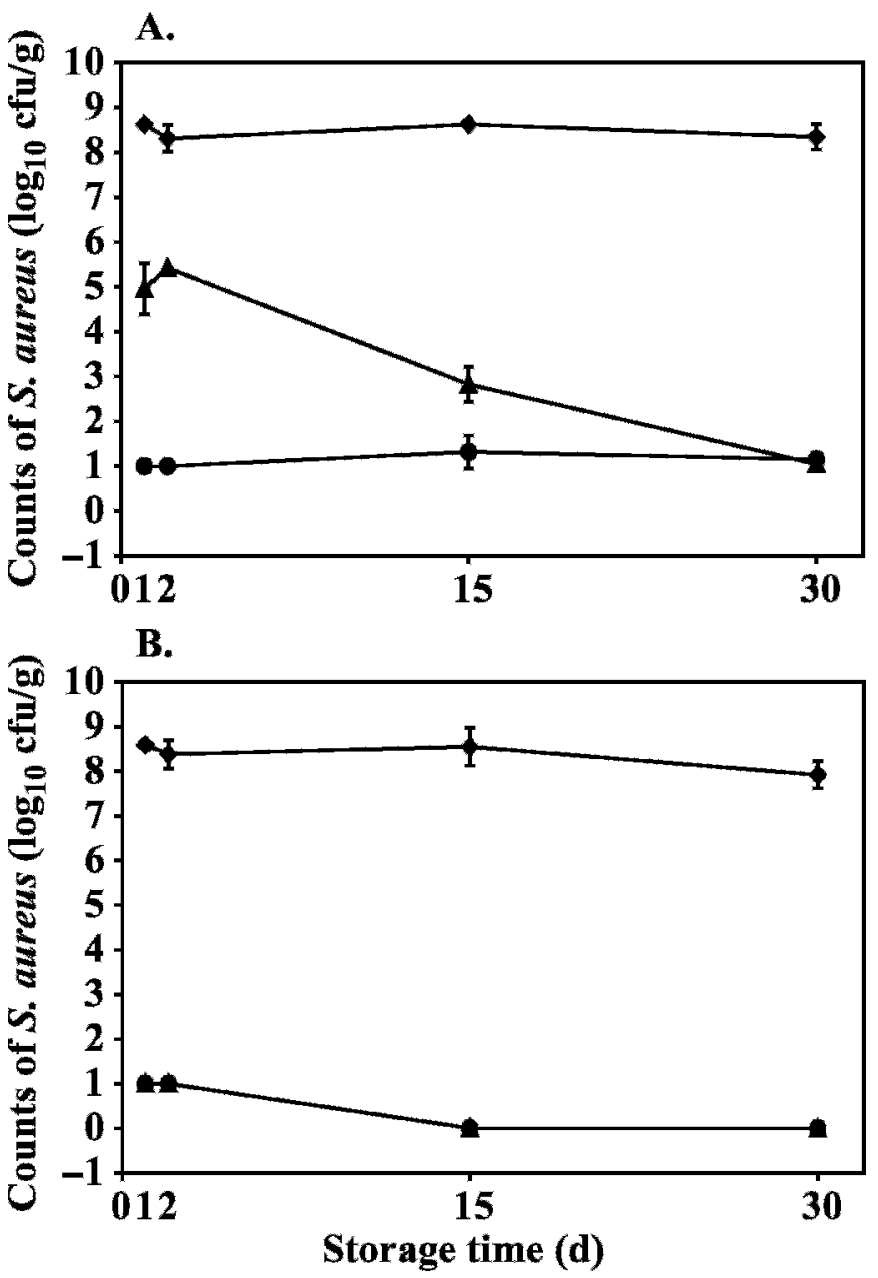

Figure 3. Evolution of counts of Staphylococcus aureus CECT 976 (expressed as means of 3 replications \pm confidence interval) in control cheeses $(\bullet)$, ultrahigh pressure homogenization (UHPH) cheeses $(\boldsymbol{\Delta})$, and in $\mathrm{UHPH}+$ high hydrostatic pressure cheeses $(\bullet)$ stored at $8^{\circ} \mathrm{C}$. A) Counts at UHPH inlet temperature of $6^{\circ} \mathrm{C}$; B) Counts at UHPH inlet temperature of $20^{\circ} \mathrm{C}$. When interval bars are not visible they fall within plot symbols.

were already below the detection limit on $\mathrm{d} 1$. After 15 d of storage at $8^{\circ} \mathrm{C}$, complete inactivation was achieved for both samples, as Staph. aureus was not recovered after incubating the initial dilution of the samples for $18 \mathrm{~h}$ at $32^{\circ} \mathrm{C}$ and streaking onto Baird Parker supplemented with rabbit plasmin fibrinogen.

\section{Evaluation of StE Formation}

As can be seen in Table 1, StE were positively detected in all our control cheese samples but were not detected in any $\mathrm{UHPH}$ or $\mathrm{UHPH}+\mathrm{HHP}$ cheese made from milk treated at both $T_{i n}$. 
Table 1. Staphylococcal enterotoxin detection in cheeses made with milk treated with ultrahigh pressure homogenization (UHPH) and $\mathrm{UHPH}+$ high hydrostatic pressure (HHP)

\begin{tabular}{lll}
\hline Cheese & $\begin{array}{l}\text { Day } 1 \text { of } \\
\text { storage at } 8^{\circ} \mathrm{C}\end{array}$ & $\begin{array}{l}\text { Day } 30 \text { of } \\
\text { storage at } 8^{\circ}\end{array}$ \\
\hline Blank & ND $^{1}$ & ND \\
Control & Positive & Positive \\
UHPH & ND & ND \\
UHPH + HHP & ND & ND \\
\hline
\end{tabular}

${ }^{1} \mathrm{ND}=$ Not detectable.

\section{DISCUSSION}

The reductions of Staph. aureus counts obtained in UHPH treated milk at both $T_{\text {in }}$ were higher than those obtained by Wuytack et al. (2002) and Diels et al. (2003) in PBS (10 mM, pH 7.0) after $300 \mathrm{MPa}$ at $T_{\text {in }}$ of $25^{\circ} \mathrm{C}$ (less than $1 \log _{10} \mathrm{cfu} / \mathrm{mL}$ ) using an Emulsiflex C5 (Avestin, Ottowa, Canada). This finding could be explained by differences between food matrices and among UHPH equipment designs (Briñez et al., 2006).

Reductions of Staph. aureus counts in milk samples as a consequence of UHPH treatments at $6^{\circ} \mathrm{C} T_{i n}$ were inferior to those obtained at $20^{\circ} \mathrm{C} T_{i n}$, probably due to the higher temperature reached after the high-pressure valve. This phenomenon was extensively described in the work of Thiebaud et al. (2003) in which it was demonstrated that for $T_{\text {in }}$ of 4 and $24^{\circ} \mathrm{C}$, the temperatures measured immediately after the high-pressure valve were $64.5 \pm 1.0$ and $78.0 \pm 1.9^{\circ} \mathrm{C}$, respectively. The authors also provide an estimation of the temperature increase due to pressure build-up and to the temperature increments after the high-pressure valve (i.e., 3.0 \pm 0.1 and $15.5 \pm 0.4^{\circ} \mathrm{C} / 100 \mathrm{MPa}$ for $T_{\text {in }}$ of $\left.24^{\circ} \mathrm{C}\right)$. As reported by Picart (2004) for pressures of $300 \mathrm{MPa}$, the use of a second $30-\mathrm{MPa}$ pressure stage in the same homogenizer reduces the temperature after the highpressure valve by approximately $5^{\circ} \mathrm{C}$. Putting all this information together and taking $T_{i n}$ values of $4^{\circ} \mathrm{C}$ for our $T_{\text {in }}$ of $6^{\circ} \mathrm{C}$, and $T_{\text {in }}$ values of $24^{\circ} \mathrm{C}$ for our $T_{\text {in }}$ of $20^{\circ} \mathrm{C}$, we estimated a maximum temperature reached after the high-pressure valve of approximately 65 and $75^{\circ} \mathrm{C}$, respectively (differences in heat transfer between the different machines may certainly exist but cannot be estimated accurately). It should be remembered that the time the fluid remains at the maximum temperature is considered to be less than $1 \mathrm{~s}$ when refrigeration systems are working (Thiebaud et al., 2003; Picart et al., 2006).

Previous and current studies show that UHPH treatments are useful to reduce regular microflora normally present in raw milk (Hayes et al., 2003; Thiebaud et al., 2003; Pereda et al., 2006; Picart et al., 2006) and indicate the possible use of UHPH as a substitute for continuous pasteurization systems. However, inactivation studies carried out in buffer suspensions or inoculated sterilized milk reveal that reductions of resistant pathogenic cells rarely surpass $3.5 \log _{10} \mathrm{cfu} / \mathrm{mL}$ (without recycling) at moderate inlet temperatures (Vachon et al., 2002; Wuytack et al., 2002, 2003; Diels et al., 2003). It is questionable whether these values are adequate to prevent foodborne intoxications caused by accidentally higher loads of pathogens inside raw milk. Furthermore, Briñez et al. (Universitat Autònoma de Barcelona, Barcelona, Spain, personal communication) have shown that Staph. aureus cells were able to maintain their counts during milk storage at $4^{\circ} \mathrm{C}(9 \mathrm{~d})$, which is contrary to what happens with more acidic liquid foods such as orange juice (Briñez et al., 2006). Concerns have already been raised (Smiddy et al., accepted) that suggest the need for further studies as well as for new developments in UHPH equipments.

For both $T_{\text {in }}$ assayed, the difference between counts of Staph. aureus in control and UHPH cheese were significantly higher than the reductions of Staph. aureus found in milk before and after UHPH treatment. Taking into consideration that temperatures higher than $37^{\circ} \mathrm{C}$ were never reached during the cheesemaking process, it seems that the interaction of pressurized Staph. aureus with healthy starter cells and relatively low $\mathrm{pH}$ somehow helped to achieve higher inactivation in cheese samples compared with milk samples.

As stated previously, Staph. aureus in control cheese samples showed its ability to survive and to not reduce in count. In pressurized samples, UHPH capability for causing damage to bacterial cells was probably coupled with the effect of the ripening process that takes place. The significant decreases of Staph. aureus counts during storage of UHPH cheese lead us to consider the existence of sublethal injury to cells as a consequence of this treatment. Sublethal injury has been studied by Wuytack et al. $(2002,2003)$ for several nonthermal treatments including UHPH; they did not find significant UHPH sublethally injured cells of Staph. aureus and Salmonella enterica serovar Typhimurium in phosphate buffered saline ( $10 \mathrm{~m} M$ potassium phosphate, $\mathrm{pH}$ $7.0,8.4 \mathrm{~g} / \mathrm{L}$ of $\mathrm{NaCl}$ ) using culture medium supplemented with $\mathrm{NaCl}$ (0 to 6\%), or SDS (0 to $100 \mathrm{mg} / \mathrm{L}$ ) or with an adjusted $\mathrm{pH}$ (5.5 to 7.0). This could not be done with our cheese samples because of the interference of starter cells in nonselective media. Nevertheless, the existence of Staph. aureus cells sublethally injured following UHPH in our cheeses cannot be discounted. The presence of these cells should be assessed by means other than growing medium criteria.

In UHPH+HHP cheese, the HHP treatment caused an additional reduction of Staph. aureus of $3.3 \log _{10}$ cfu/g compared with UHPH cheese at $T_{\text {in }}$ of $6^{\circ} \mathrm{C}$. This 
value was higher than the $1.4 \pm 0.2 \log _{10} \mathrm{cfu} / \mathrm{g}$ obtained by López-Pedemonte et al. (2007) after applying the same HHP treatment to the same Staph. aureus strain in a pasteurized model cheese. These figures provide additional support to the existence of cells sublethally damaged by UHPH and to the hypothesis of obtaining a synergistic effect by combining both technologies. After the 30-d storage period, for both UHPH and $\mathrm{UHPH}+\mathrm{HHP}$ samples, similar reductions of $7.3 \pm 0.2$ and $7.2 \pm 0.2 \log _{10} \mathrm{cfu} / \mathrm{g}$, respectively, were found. Nevertheless, the combination of a HHP treatment caused a sharper decrease of counts of Staph. aureus, which can be seen comparing the counts on $\mathrm{d} 15(P<0.001)$.

For UHPH samples, total inactivation of cells at $T_{\text {in }}$ of $20^{\circ} \mathrm{C}$ was achieved on d 15 (unlike for $T_{\text {in }}$ of $6^{\circ} \mathrm{C}$ ), which meant a reduction of more than $8.0 \log _{10} \mathrm{cfu} / \mathrm{g}$ for UHPH treatment alone. Taking all this into account, the advantage of adding the HHP treatment has to be evaluated in view of the desired $T_{i n}$ and ripening time. The combination of both pressure treatments implies higher costs (higher energy, time consumption, and equipment investment) as well as increased modification of the original cheese matrix.

Staphylococcal enterotoxins were detected in all our control cheese samples. Conditions under which StE can be produced are as follows: 10 to $48^{\circ} \mathrm{C}$ temperature, $\mathrm{pH} 4.0$ to 9.6 , and water activity of 0.84 to 0.99 (Asperger, 1994; Belay and Rasooly, 2002; European Union, 2003). A Staph. aureus load of $5 \log _{10} \mathrm{cfu} / \mathrm{g}$ of food has been suggested as an amount that would allow enough enterotoxin formation to cause illness, probably within $2 \mathrm{~h}$ (Belay and Rasooly, 2002). All these conditions could be met in our model cheeses, except for the fact that the storage temperature was below $10^{\circ} \mathrm{C}$. This temperature was chosen as a common ripening temperature of some Spanish cheeses and to prevent StE production during ripening as well. In this experiment, the initial Staph. aureus load was higher than $7 \log _{10} \mathrm{cfu} /$ $\mathrm{mL}$ of milk. The UHPH treatment reduced its counts to $3.6 \pm 0.3 \log _{10} \mathrm{cfu} / \mathrm{mL}$ for $T_{\text {in }}$ of $20^{\circ} \mathrm{C}$ but only to 5.5 $\pm 0.1 \log _{10} \mathrm{cfu} / \mathrm{mL}$ for $T_{\text {in }}$ of $6^{\circ} \mathrm{C}$. Even when the cheesemaking temperature was around $37^{\circ} \mathrm{C}$ for more than 3 $\mathrm{h}$ (and never surpassed it), StE could not be detected in any UHPH or UHPH+HHP cheese.

This study shows a new approach for improving cheese safety by using UHPH to treat inoculated milk before cheese making and by additionally applying HHP to cheese as an alternative. Raw milk used to make cheese is expected to contain no more than 5.5 $\log _{10} \mathrm{cfu} / \mathrm{mL}$ of aerobic bacteria and no more than 3.3 $\log _{10} \mathrm{cfu} / \mathrm{mL}$ of Staph. aureus (European Union, 1992). Provided that at least $7 \log _{10} \mathrm{cfu} / \mathrm{g}$ reductions were achieved and StE formation prevented, it seems reasonable to suppose that UHPH, and UHPH combined with
HHP, can be successfully used to improve the safety of soft-curd cheeses made from raw milk. Inlet UHPH milk temperatures can be in the 6 to $20^{\circ} \mathrm{C}$ range when the initial load of bacteria is not extremely elevated. Nevertheless, the choice of $T_{i n}$ must take into consideration the impact on whey protein denaturation, modification of structural properties of casein micelles, the rheological characteristics of the curds obtained, alteration of enzymatic activities (plasmin, alkaline phosphatase, lactoperoxidase, lipase), and fat globule size reduction (Thiebaud et al., 2003; Hayes et al., 2004; Datta et al., 2005; Sandra and Dalgleish, 2005; Lanciotti et al., 2006; Picart et al., 2006).

\section{ACKNOWLEDGMENTS}

This study was supported financially by project CAL00-005-C2-1 (Instituto Nacional de Investigación y Tecnologiá Agraria y Alimentaria). The authors acknowledge the grant given to Wilfido José Briñez Zambrano by the Fondo Nacional para la Ciencia y la Tecnologa (FONACIT) of Venezuela and the grant given to Tomás López-Pedemonte by the Agència de Gestió d'Ajuts Universitaris i de Recerca de la Generalitat de Catalunya. The authors also thank the Colección Española de Cultivos Tipo for providing the strains and the collaboration of Sonia Llorenç and María Penengo.

\section{REFERENCES}

Arqués, J. L., E. Rodríguez, P. Gaya, M. Medina, B. Guamis, and M. Nuñez. 2005. Inactivation of Staphylococcus aureus in raw milk cheese by combinations of high-pressure treatments and bacteriocin producing lactic acid bacteria. J. Appl. Microbiol. 98:254-260.

Asperger, H. 1994. Staphylococcus aureus. Pages 24-42 in The Significance of Pathogenic Microorganisms in Raw Milk. Bulletin of the International Dairy Federation, Brussels, Belgium.

Balaban, N., and A. Rasooly. 2000. Staphylococcal enterotoxins. Int. J. Food Microbiol. 61:1-10.

Belay, N., and A. Rasooly. 2002. Staphylococcus aureus growth and enterotoxin A production in an anaerobic environment. J. Food Prot. 65:199-204.

Briñez, W. J., A. X. Roig-Sagués, M. M. Hernández-Herrero, and B. Guamis. 2006. Inactivation of Listeria innocua in milk and orange juice using ultra high pressure homogenisation. J. Food Prot. 69:199-204.

Brisabois, A., V. Lafarge, A. Brouillaud, M. L. De Buyser, C. Collette, B. Garin-Bastuji, and M.-F. Thorel. 1997. Les germes pathogens dans le lait et les produits laitiers: Situation en France et en Europe. Rev.-Off. Int. Epizoot. 16:452-471.

Bunning, V. K., J. A. Lindsay, and D. L. Archer. 1997. Chronic health effects of microbial foodborne disease. World Health Stat. Q. 50:51-56.

Cenci-Goga, B. T., M. Karama, P. V. Rossitto, R. A. Morgante, and J. S. Cullor. 2003. Enterotoxin production by Staphylococcus aureus isolated from mastitic cows. J. Food Prot. 66:1693-1696.

Coveney, H. M., G. F. Fitzgerald, and C. Daly. 1994. A study of the microbiological status of Irish farmhouse cheeses with emphasis on selected pathogenic and spoilage micro-organisms. J. Appl. Microbiol. 77:621-630.

Datta, N., M. G. Hayes, H. C. Deeth, and A. L. Kelly. 2005. Significance of frictional heating for effects of high pressure homogenisation on milk. J. Dairy Res. 72:1-7. 
Diels, A. M. J., E. Y. Wuytack, and C. W. Michiels. 2003. Modelling inactivation of Staphylococcus aureus and Yersinia enterocolitica by high-pressure homogenisation at different temperatures. Int. J. Food Microbiol. 87:55-62.

European Union. 1992. Laying down the health rules for the production and placing on the market of milk, heat treated milk and milk based products. EU Council directive 92/46/EEC of 16 June 1992. Off. J. L 268:0001-0032.

European Union. 2003. Opinion of the scientific committee on veterinary measures relating to public health on staphylococcal enterotoxins in milk products, particularly cheeses. European Commission, Health and Consumer Protection Directorate-General, 26 to 27 March 2003. Online. http://ec.europa.eu/food/fs/sc/scv/ outcome_en.html

Floury, J., J. Bellettre, J. Legrand, and A. Desrumaux. 2004. Analysis of a new type of high pressure homogeniser. A study of the flow pattern. Chem. Eng. Sci. 59:843-853.

Floury, J., A. Desrumaux, M. A. V. Axelos, and J. Legrand. 2002. Degradation of methylcellulose during ultra-high pressure homogenisation. Food Hydrocoll. 16:47-53.

Gervilla, R., E. Sendra, V. Ferragut, and B. Guamis. 1999. Sensitivity of Staphylococcus aureus and Lactobacillus helveticus in ovine milk subjected to high hydrostatic pressure. J. Dairy Sci. 82:1099-1107.

Hayes, M. G., P. F. Fox, and A. L. Kelly. 2004. Potential applications of high-pressure homogenisation in processing of milk. J. Dairy Res. 71:1-9.

Hayes, M. G., and A. Kelly. 2003. High pressure homogenization of raw whole bovine milk (a) effects on fat globule size and other properties. J. Dairy Res. 70:297-305.

Jablonski, L. M., and G. Bohach. 2001. Staphylococcus aureus. Pages 411-434 in Food Microbiology: Fundamentals and Frontiers. M. P. Doyle, L. R. Beuchat, and T. J. Montville, ed. ASM Press, Washington, DC.

Juan, B., V. Ferragut, B. Guamis, M. Buffa, and A. Trujillo. 2004. Proteolysis of a high-pressure treated ewe's milk cheese. Milchwissenschaft 59:616-619.

Lanciotti, R., L. Vaninni, F. Patrignani, L. Iucci, M. Valicelli, M. Ndagijimana, and M. E. Guerzoni. 2006. Effect of high pressure homogenization of milk on cheese yield and microbiology, lipolysis and proteolysis during ripening of Caciotta cheese. J. Dairy Res. 73:216-226.

López-Pedemonte, T., A. Roig-Sagués, M. Capellas, A. Trujillo, and B. Guamis. 2003. Inactivation of spores of Bacillus cereus in cheese by high hydrostatic pressure with the addition of nisin or lysozyme. J. Dairy Sci. 86:3075-3081.

López-Pedemonte, T., A. Roig-Sagués, S. De Lamo, R. Gervilla, and B. Guamis. 2007. High hydrostatic pressure treatment applied to model cheeses made from cow's milk inoculated with Staphylococcus aureus. Food Contr. 18:441-447. doi:10.1016/j.foodcont. 2005.11.012

Malone, A. S., C. Wick, T. H. Shellhammer, and P. D. Courtney. 2003. High pressure effects on proteolytic and glycolytic enzymes involved in cheese manufacturing. J. Dairy Sci. 86:1139-1146.

Middelberg, A. P. J. 1995. Process-scale disruption of microorganisms. Biotechnol. Adv. 13:491-551.

Moroni, O., J. Jean, J. Autret, and I. Fliss. 2002. Inactivation of lactococcal bacteriophages in liquid media using dynamic high pressure. Int. Dairy J. 12:907-913.

O’Reilly, C. E., A. L. Kelly, P. M. Murphy, and T. P. Beresford. 2001. High pressure treatment: Application in cheese manufacture and ripening. Trends Food Sci. Technol. 12:51-59.
O'Reilly, C. E., P. M. O’Connor, A. L. Kelly, T. P. Beresford, and P. M. Murphy. 2000. Use of hydrostatic pressure for inactivation of microbial contaminants in cheese. Appl. Environ. Microbiol. $66: 4890-4896$.

Patterson, M. F. 2005. Microbiology of pressure-treated foods. J. Appl. Microbiol. 98:1400-1409.

Patterson, M. F., M. Quinn, R. Simpson, and A. Gilmour. 1995. The sensitivity of vegetative pathogens to high hydrostatic pressure treatments in phosphate-buffered saline and foods. J. Food Prot. 58:524-529

Pereda, J., V. Ferragut, B. Guamis, and A. J. Trujillo. 2006. Effect of ultra high-pressure homogenisation on natural-occurring microorganisms in bovine milk. Milchwissenschaft 61:245-248.

Picart, L. 2004. New food preservation processing: Pulsed electric fields, high pressure treatments combined with low temperatures, high pressure homogenisation. Characterisation of operational conditions and microbial inactivation. $\mathrm{PhD}$ Thesis, Université de Montpellier II, Montpellier, France.

Picart, L., M. Thiebaud, M. René, J. P. Guiraud, J. C. Cheftel, and E. Dumay. 2006. Effects of high pressure homogenization of raw bovine milk on alkaline phosphatase and microbial inactivation. A comparison with continuous short-time thermal treatments. J. Dairy Res. 73:1-10.

Rowan, N. J., S. J. MacGregor, J. G. Anderson, D. Cameron, and O. Farish. 2001. Inactivation of Mycobacterium paratuberculosis by pulsed electric fields. Appl. Environ. Microbiol. 67:2833-2836.

Sandra, S., and D. G. Dalgleish. 2005. Effects of ultra-high-pressure homogenization and heating on structural properties of casein micelles in reconstituted skim milk powder. Int. Dairy J. 15:1095-1104.

Thiebaud, M., E. Dumay, L. Picart, J. P. Guiraud, and J. C. Cheftel. 2003. High-pressure homogenization of raw bovine milk. Effects on fat globule size distribution and microbial inactivation. Int. Dairy J. 13:427-439.

Trujillo, A. J., M. Capellas, J. Saldo, R. Gervilla, and B. Guamis. 2002. Applications of high-hydrostatic pressure on milk and dairy products: A review. Innov. Food Sci. Technol. 3:295-307.

Smiddy, M. A., J. E. Martin, T. Huppertz, and A. L. Kelly. Microbial shelf-life of high-pressure-homogenized milk. Int. Dairy J. (accepted)

Shakeel-Ur-Rehman, P. L. H. McSweeney, and P. L. H. Fox. 1998. A protocol for the manufacture of miniature cheeses. Lait 78:607-620.

Vachon, J. F., E. E. Kheadr, J. Giasson, P. Paquin, and I. Fliss. 2002. Inactivation of foodborne pathogens in milk using dynamic high pressure. J. Food Prot. 65:345-352.

Wick, C., U. Nienaber, O. Anggraeni, T. H. Shellhammer, and P. D. Courtney. 2004. Texture, proteolysis and viable lactic acid bacteria in commercial Cheddar cheeses treated with high pressure. J. Dairy Res. 71:107-115.

Wuytack, E. Y., A. M. J. Diels, and Ch. W. Michiels. 2002. Bacterial inactivation by high-pressure homogenisation and high hydrostatic pressure. Int. J. Food Microbiol. 77:205-212.

Wuytack, E. Y., L. Duong Thi Puong, A. Aertsen, K. M. F. Reyns, D. Marquenie, B. de Ketelaere, B. Masschalk, I. Van Opstal, A. M. J. Diels, and C. W. Michiels. 2003. Comparison of sublethal injury induced in Salmonella enterica serovar Typhimurium by heat and by different non thermal treatments. J. Food Prot. 66:31-37.

Younis, A., O. Krifucks, E. D. Heller, Z. Samra, A. Glickman, A. Saran, and G. Leitner. 2003. Staphylococcus aureus exosecretions and bovine mastitis. J. Vet. Med. B. 50:1-7. 